\title{
Beta-cell proliferation in normal and streptozotocin-treated newborn rats: site, dynamics and capacity
}

\author{
R. N. Wang, L. Bouwens, G. Klöppel \\ Department of Experimental Pathology, Free University of Brussels, Campus Jette, Brussels, Belgium
}

Summary Regeneration of neonatal beta cells after streptozotocin (STZ)-induced destruction may be due to either replication from pre-existing intra-islet beta cells or extra-islet precursor cells. To further investigate this issue, beta-cell growth was analysed in normal and streptozotocin-treated newborn rats $(100 \mu \mathrm{g} / \mathrm{g}$ body weight) at several time points during the first 20 days of life. Beta cells were identified by insulin immunostaining, non-isotopic in situ hybridization for rat preproinsulin mRNA, and electron microscopy. Their proliferative activity was recorded by bromodeoxyuridine-pulse labelling. Beta-cell size and total volume were determined by computerized morphometry. In normal rats, there was a threefold increase in total beta-cell volume during the first 5 days of life, with no further expansion till day 20. The bromodeoxyuridine labelling index of the intraislet beta cells was smaller than that of the extra-islet beta cells ( $2-3 \%$ vs $15-20 \%$ ). Comparison of the cell birth rate, calculated from the beta-cell labelling index, with the observed increase in beta-cell volume suggested that in normal neonatal rats proliferation of the intra-islet beta-cell population could account for only $10 \%$ of the observed expansion. Administration of streptozotocin at birth resulted in more than $90 \%$ reduction of the total beta-cell volume at day 2 , which then increased to $39 \%$ of the normal value by day 20. During this period of partial regeneration, which restored normoglycaemia, the labelling index of intra-islet beta cells was higher than in normal rats $(9 \%$ vs $2 \%, p<0.001)$, whereas no change was seen in the extra-islet beta-cell labelling index. Comparison of cell birth rate with the increase in betacell volume indicated that $50-60 \%$ of the observed beta-cell growth could result from the intra-islet beta-cell proliferation. These results suggest that replication from pre-existing, surviving beta cells plays an important role in regeneration of neonatal beta cells after destruction by streptozotocin. [Diabetologia (1994) 37: 1088-1096]

Key words Streptozotocin diabetes, neonatal rat, beta-cell proliferation, immunocytochemistry, morphometry.
The study of the growth potential of pancreatic beta cells has elicited considerable interest during recent years because of its implications for the understand-

Received: 4 April 1994

and in revised form: 1 June 1994

Corresponding author: Professor G. Klöppel, Department of Experimental Pathology, Free University of Brussels, Campus Jette, Laarbeeklaan 103, B-1090 Brussels, Belgium

Abbreviations: STZ, Streptozotocin; BrdU, bromodeoxyuridine; DIG, digoxigenin; SSC, sodium chloride, sodium citrate; LI, labelling index. ing of the pathogenesis of diabetes and potential treatment of this disease [1-3]. In the rat fetus, quantitation of the mitotic activity within islets has demonstrated that the replication of differentiated islet cells is insufficient to explain the observed increase in endocrine tissue [4-5]. Therefore, neogenesis of islet cells is thought to occur through differentiation of precursor cells which probably stem from the ductal cell pool [6-11]. This mechanism, which appears to continue in the early postnatal period, was also proposed to account for the observed regeneration of beta cells after their destruction by streptozotocin (STZ) [12-13]. However, other investigators have re- 
ported an elevated mitotic activity of islet cells in STZ-treated neonatal rats and concluded that pre-existing, differentiated beta cells that survived the STZdamage are responsible for beta-cell regeneration [14-16].

The purpose of the present study was to get further insight into the process of regeneration of neonatal beta cells after their subtotal destruction by STZ. Therefore, we determined site, dynamics and capacity of beta-cell proliferation in normal and STZ-treated neonatal rats by using immunocytochemical double staining for the thymidine analogue bromodeoxyuridine (BrdU) and pancreatic hormones combined with computer-assisted morphometry. Not yet granulated or severely degranulated beta cells were identified by non-isotopic in situ hybridization.

\section{Materials and methods}

Animals and tissue processing. Newborn Wistar rats (Katholieke Universiteit Leuven, Proefdierencentrum, Heverlee, Belgium) were divided randomly into two groups, the STZ group and the normal control group. Within $12 \mathrm{~h}$ after birth, animals of the STZ group received a single intraperitoneal injection of $100 \mu \mathrm{g}$ streptozotocin (Sigma, St. Louis, Mo., USA) per gram body weight, freshly dissolved in citrate buffer $\mathrm{pH}$ 4.5 as described previously [17]. Controls were injected with the equivalent volume of citrate buffer. Animals were fed ad libitum throughout the study and kept in an environment of constant temperature, humidity and day-night cycle. Control and STZ-treated rats were killed by decapitation $0,2,5,9,13$ and 20 days after birth. Eight to fourteen rats per time point and group were studied. One hour before decapitation, animals from both STZ and control groups were injected intraperitoneally with 5-bromo-2-deoxyuridine (BrdU) (Boehringer Mannheim, Germany) dissolved in phosphate buffered saline, at a dose of $50 \mathrm{mg} / \mathrm{kg}$ body weight [18].

Body weights of the neonatal rats were assessed at the onset and the end of the experiment. Blood glucose measurements were taken on the day of decapitation with a Glucoscot II device (Kyoto Daiichi Kagaku Co. Ltd, Kyoto, Japan). The whole pancreas was excised and its volume determined according to Archimedes' principle by immersion in saline solution [19]. The tissue was then fixed in $4 \%$ paraformaldehyde overnight, dehydrated and embedded in paraffin according to a standardized protocol. Pieces of pancreatic tissue from rats killed on days 2 and 5 were fixed in $2.5 \%$ (volume/volume) glutaraldehyde for electron microscope examination.

Double immunocytochemistry. Two sets of six serial sections (section thickness $3 \mu \mathrm{rn}$ ) were cut from the paraffin blocks at $60-\mu \mathrm{m}$ intervals. The sections were first immunostained for BrdU using the ABC/HRP method (streptavidin-biotin horseradish peroxidase complex; Dako, Glostrup, Denmark) and developed with DAB (3,3-diaminobenzidinetetrahydrochloride; Sigma, St. Louis, Mo., USA) [18]. DNA denaturation was obtained by incubating the sections with 2 normals $\mathrm{HCl}$ for 30 min at $37^{\circ} \mathrm{C}$, and $\mathrm{BrdU}$ was detected by mouse monoclonal anti-BrdU antibody (Euro-Diagnostics, Apeldoorn, The Netherlands) diluted 1:10, overnight at $4^{\circ} \mathrm{C}$. The same tissue sections were then stained with a mouse monoclonal anti-insulin antibody (Biogenex, San Ramon, Calif., USA) or with a mix- ture of mouse monoclonal anti-glucagon (diluted 1:1000) and somatostatin (diluted 1:5000) antibodies (Novo Nordisk, Gentafte, Denmark). These monoclonal antibodies were detected using the ABC/AP method (streptavidin-biotin-alkaline phosphatase complex) and NAMP/Fast Red (naphtol-AS-MXphosphate/fast red TR salt, Sigma) as chromogen to obtain a red reaction. Negative controls for the staining techniques consisted of omission of the 2 normals $\mathrm{HCl}$ treatment (BrdU), or omission of the primary antibodies. These tests resulted in negative staining reactions.

In situ hybridization. For detection of preproinsulin mRNA, cocktails of six synthetic single stranded oligonucleotide probes ( 30 mers) were used. They were chemically labelled at their 5 ends with digoxigenin (DIG) (British Biotechnology Products Ltd, Abingdon, UK). The in situ hybridization protocol used in the present study was essentially that of Komminoth [20]. Consecutive sections $(3 \mu \mathrm{m})$ from normal and STZ-treated neonatal rats at days 2 and 5 were mounted on sialinized slides and deparaffinized and rehydrated through graded concentrations of ethanol. Pretreatment consisted of the following steps: $0.2 \mathrm{~mol} \mathrm{HCl}$ for $20 \mathrm{~min}, 0.3 \%$ Triton X-100 for $15 \mathrm{~min}$, proteinase $\mathrm{K}$ at $10 \mu \mathrm{g} / \mathrm{ml}$ in proteinase $\mathrm{K}$-buffer for $30 \mathrm{~min}$ at $37^{\circ} \mathrm{C}, 0.2 \%$ glycine for $1 \mathrm{~min}$ and $4 \%$ paraformaldehyde for $5 \mathrm{~min}$ at $4{ }^{\circ} \mathrm{C}$. The sections were prehybridized for $3 \mathrm{~h}$ at $37^{\circ} \mathrm{C}$ in a solution containing $50 \%$ deionized formamide and $2 \times$ sodium chloride, sodium citrate (SSC) and hybridized for $16 \mathrm{~h}$ at $37^{\circ} \mathrm{C}$. The final hybridization solution contained $50 \%$ deionized formamide, $10 \%$ dextran sulphate, $1 \times$ Denhardt's solution, $4 \times \mathrm{SSC}, 250 \mu \mathrm{g} / \mathrm{ml}$ yeast t-RNA, $500 \mu \mathrm{g} / \mathrm{ml}$ herring sperm DNA and $150 \mathrm{ng} / \mathrm{ml}$ DIG-preproinsulin mRNA probes. Post-hybridization washes were through graded concentrations of SSC solution. Slides were then incubated for $30 \mathrm{~min}$ in $0.3 \%$ TritonX-100 and $2 \%$ normal sheep serum, followed by an incubation for $3 \mathrm{~h}$ at room temperature with alkaline phosphatase-conjugated polyclonal sheep anti-DIG antibody (diluted 1:1000, Boehringer Mannheim). The reaction product was visualised by an enzyme-catalysed colour reaction using nitro blue tetrazolium and 5-bromo-4-chloro-3-indolyl-phosphate medium, containing $1 \mathrm{mmol} / \mathrm{l}$ levamisole (Sigma) to block endogenous alkaline phosphatase activity. Sections were incubated in a dark box overnight at room temperature until the coloured reaction product developed at the sites of hybridization. The reaction was stopped by placing slides in $10 \mathrm{mmol} / 1$ Tris- $\mathrm{HCl} \mathrm{pH}$ 8.1 and $1 \mathrm{mmol} / 1$ EDTA $\mathrm{pH}$ 8.0. The specificity of preproinsulin mRNA oligonucleotide probes was tested by omission of the probes and pretreatment of tissue sections with RNase $\left(100 \mu \mathrm{l} / \mathrm{ml}\right.$ in $2 \times \mathrm{SSC} / 10 \mathrm{mmol} / 1 \mathrm{MgCl}_{2}$ at $37^{\circ} \mathrm{C}$ for $1 \mathrm{~h}$ ), which abolished all reactivity.

Morphometry. To determine the beta-cell volume density in the pancreas, each gland was sectioned throughout its length to avoid any bias due to regional variation in islet distribution and cell composition. Islets were defined arbitrarily as endocrine cell aggregations composed of more than three insulinimmunoreactive cells associated with more than three glucagon somatostatin immunoreactive cells. All other endocrine cell aggregations were considered extra-islet cell clusters. The total area of the pancreatic section was measured as well as the total insulin-immunoreactive area inside (intra-islet) and outside the islets (extra-islet). Areas of islets and single cells were traced manually. This was done with a Zeiss Axiophot microscope connected by a colour video camera to a Macintosh Quadra 700 computer, and using existing software (NIH Image 1.41). The total beta-cell volume was calculated by the stereological equation [21]: $\mathrm{A} / \mathrm{Ap}=\mathrm{V} / \mathrm{Vp}(\mathrm{A}=$ total insulin-posi- 
Table 1. Body weight and pancreatic volume of normal and STZ-treated neonatal rats at different time points

\begin{tabular}{|c|c|c|c|c|}
\hline \multirow[t]{2}{*}{ Day } & \multicolumn{2}{|l|}{ Body weight (g) } & \multicolumn{2}{|c|}{ Pancreatic volume $\left(\mathrm{mm}^{3}\right)$} \\
\hline & Control & STZ & Control & STZ \\
\hline 0 & $6.32 \pm 0.16(9)$ & ND & $27.78 \pm 2.22$ & ND \\
\hline 2 & $7.98 \pm 0.11(14)$ & $6.92 \pm 0.19(14)^{\mathrm{a}}$ & $29.28 \pm 0.89$ & $28.57 \pm 2.06$ \\
\hline 5 & $12.05 \pm 0.29(14)$ & $9.73 \pm 0.44(14)^{\mathrm{a}}$ & $38.93 \pm 1.07$ & $34.62 \pm 1.55^{b}$ \\
\hline 9 & $19.50 \pm 0.90(8)$ & $18.10 \pm 0.93(8)$ & $47.50 \pm 2.50$ & $46.25 \pm 2.63$ \\
\hline 13 & $26.94 \pm 0.57(9)$ & $24.29 \pm 1.66(9)$ & $70.00 \pm 2.21$ & $68.89 \pm 3.80$ \\
\hline 20 & $43.90 \pm 2.20(8)$ & $40.70 \pm 1.49(9)$ & $133.75 \pm 6.25$ & $133.75 \pm 7.06$ \\
\hline
\end{tabular}

Values are means \pm SEM with numbers of animals in parentheses. ND, not done.

${ }^{a} p<0.001 ;{ }^{b} p<0.05$ vs control

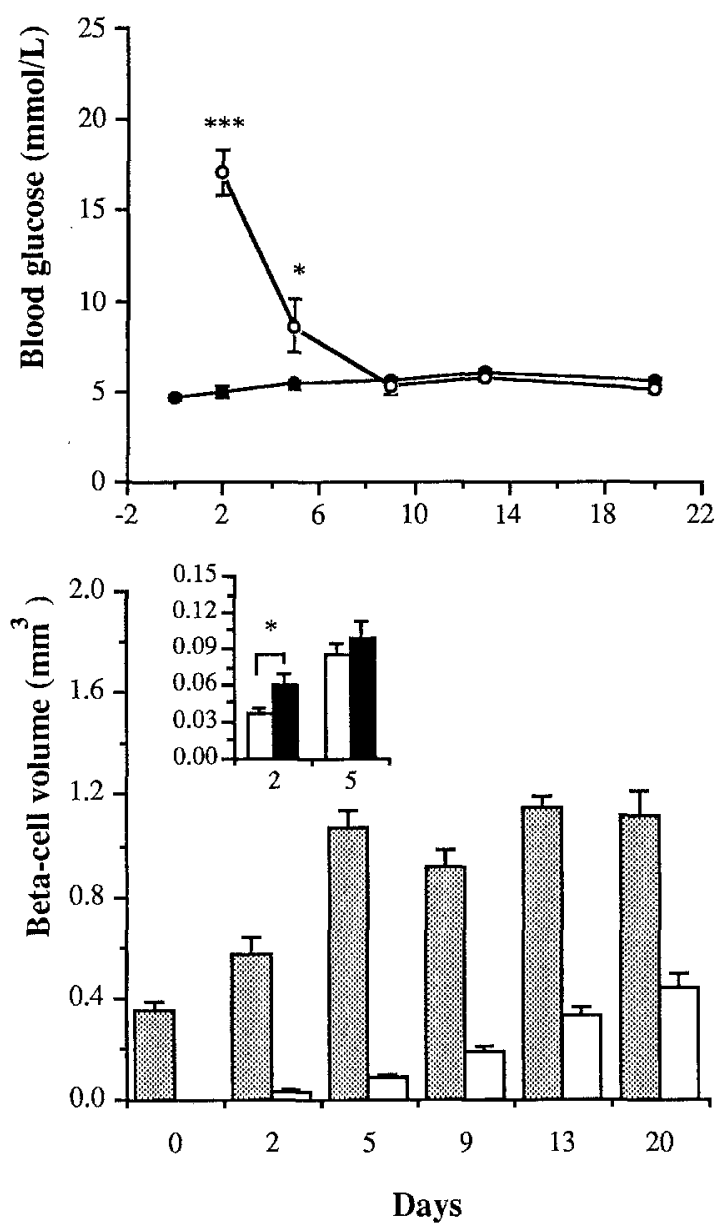

Fig.1. Blood glucose levels (top, Control, O STZ) and total beta-cell volumes (bottom, 圈 Control, $\square$ STZ) of normal and STZ-treated neonatal rats during the first 20 days of life. Statistical analysis of beta-cell volume showed significant differences between the two groups at all time points $(p<0.001)$. In the STZ-group, beta-cell volume based on immunocytochemical $(\square)$ or in situ hybridization ( $\square$ ) results significantly differed at day 2 (bottom inset). ${ }^{*} p<0.05 ; * * * p<0.001$

tive area; $A p=$ total pancreatic section area; $V=$ volume of beta cells; $\mathrm{Vp}=$ volume of pancreas).

To determine the cellular profile area of individual intra-islet or extra-islet insulin-immunoreactive cells, two randomly selected sections from each time point were used to measure the first ten insulin-immunoreactive islet areas, which were then divided by the number of insulin-immunoreactive cells in these islets. The same was done with the insulin-immunoreactive cells in the extra-islet compartment.

To calculate the BrdU labelling index, the number of cells which were positive for both insulin and BrdU in and outside the islets was determined and expressed as a mean percentage of BrdU labelling index of beta cells. The area of glucagon-somatostatin cell immunoreactivity and the number of BrdU labelling index of these cells were similarly determined.

Calculation of proliferative and growth parameters. The method for estimating the cell birth rate has previously been described in detail by Swenne [22]. The labelling index represents the fraction of cells in S-phase. Assuming the S-phase duration of beta cells (Ts) to be $6.4 \mathrm{~h}$ [15], the cell birth rate (CBR, i.e. the production of new cells per $24 \mathrm{~h}$ ) can be calculated with the equation: $\mathrm{CBR}=(\mathrm{LI} / \mathrm{Ts}) 24 \mathrm{~h}$. The growth rate of beta cells $\left(\mathrm{K}_{\mathrm{G}}\right)$ was calculated with the equation: $\mathrm{K}_{\mathrm{G}}=(\mathrm{Vt} / \mathrm{Vo}) 1 / \mathrm{t}\left(\mathrm{K}_{\mathrm{G}}=\right.$ growth rate of beta cells; $\mathrm{Vt}=$ the volume of beta cells on a certain time point; $\mathrm{Vo}=$ the volume of beta cells on a time point before $\mathrm{Vt} ; \mathrm{t}=$ the time between $\mathrm{Vt}$ and Vo.) [23]. The data are expressed as fractional increase per day $\left(\right.$ cells $\cdot$ cell $^{-1} \cdot$ day $\left.^{-1}\right)$.

\section{Statistical analysis}

Values are expressed as mean \pm SEM. Differences between the control and STZ-group rats were evaluated using unpaired Student's $t$-test for independent observations.

\section{Results}

Body weight, blood glucose levels and pancreatic volume. Normal neonatal rats showed a seven-fold increase in body weight from the day of birth to day 20. In the STZ-treated rats this weight increase was markedly retarded (Table 1). Two days after STZ treatment, the blood glucose peaked, subsequently it decreased and, by day 9, was no longer different from that of controls (Fig. 1, top). Pancreatic volume increased slowly during the first 9 days of life and expanded markedly thereafter. There were no differences in the pancreatic volumes between normal and STZ rats, except on day 5.

Morphology. On day 2, the normal neonatal pancreas showed numerous differently sized endocrine cell 


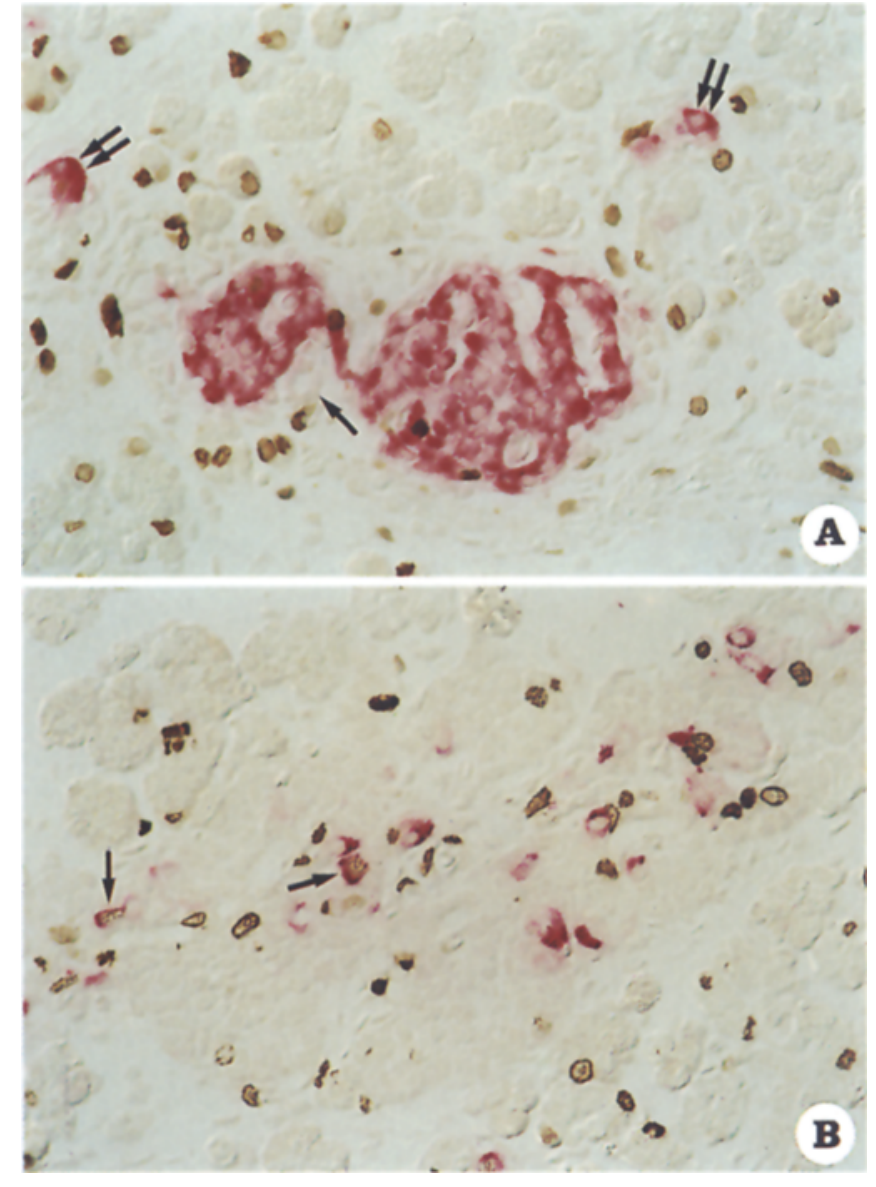

Fig. 2A, B. Double BrdU-insulin immunostaining of beta-cells of a neonatal normal (A) and STZ-treated (B) rat on day 2. (A) Islet adjacent to a duct (arrow). Extra-islet beta-cell cluster (double arrow). (B) Scattered insulin-immunoreactive cells within and outside an islet. Arrow indicates BrdU labelled cell. Original magnification, $\times 400$

clusters which were randomly scattered throughout the acinar tissue. Endocrine cell clusters composed of more than three insulin-immunoreactive cells associated with more than three glucagon or somatostatin cells or both were considered as islets. All the smaller endocrine cell aggregations were considered as extraislet cell clusters (Fig. 2A). Electron microscopically, these extra-islet beta cells were often found, either alone or in association with a single non beta cell, closely associated with or incorporated into the ductular epithelium. When lying between the ductular cells, they failed to reach the ductal lumen (Fig. 3). During the subsequent days the islets became more prominent and the number of extra-islet-cell clusters decreased gradually.

On day 2, the pancreas of STZ-treated rats showed a severe reduction in insulin-immunoreactive cells (Fig. 2B), mainly in the well-defined areas which according to their number and arrangement of nonbeta cells represented islets. Some of the intra-islet beta cells appeared to be partially degranulated. The reduction and degranulation of beta cells in the ex-

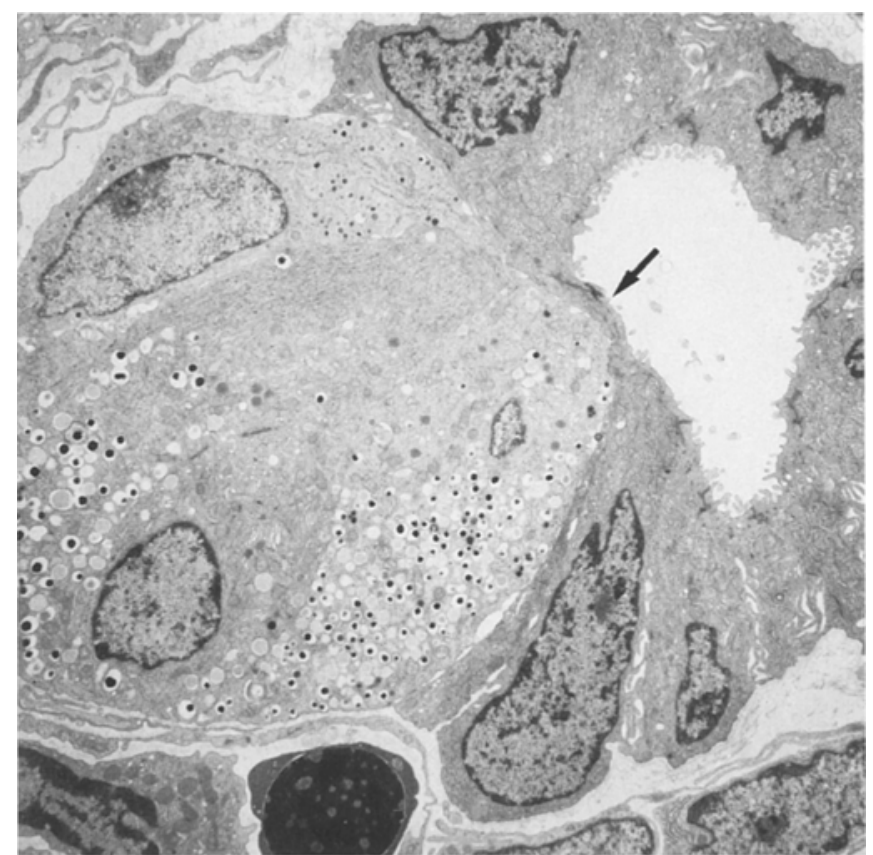

Fig.3. Electron micrograph of neonatal rat pancreas on day 2, showing beta cells in close contact with the ductular epithelium. Note that the beta cells do not reach the ductal lumen (arrow). $\times 5400$

tra-islet-cell compartment was much less severe. Electron microscopically, mitotic figures were observed in a few of the surviving beta cells. During the subsequent days, the relative number of beta cells within the islets and their insulin-immunoreactivity gradually increased, while the extra-islet beta-cell compartment did not change very much.

To identify all beta cells regardless of their secretory granule content, ISH for rat preproinsulin mRNA was performed on days 2 and 5 (Fig. 4). In controls, there were no differences between the number of beta cells detected by in situ hybridization or immunocytochemistry. In the STZ group, immunocytochemical staining revealed $37 \%$ fewer beta cells in the islets on day 2 than in situ hybridization $(p<0.005)$ (see also Fig. 1). This difference was less pronounced for extra-islet beta cells (17\%; NS). On day 5 , the difference between immunocytochemistry and in situ hybridization was no longer statistically significant (data not shown).

BrdU labelling index. The BrdU labelling index of beta cells in control and STZ rats as determined by double immunocytochemical staining (Fig. 2) is shown in Fig. 5. The BrdU labelling of intra-islet beta cells gradually decreased in the control group with time. In STZ rats, the BrdU labelling index for intra-islet beta cells was higher than that of controls, while the BrdU labelling index of extra-islet beta cells was similar in normal and STZ-treated rats. The BrdU labelling index of non-beta cells (alpha- and 


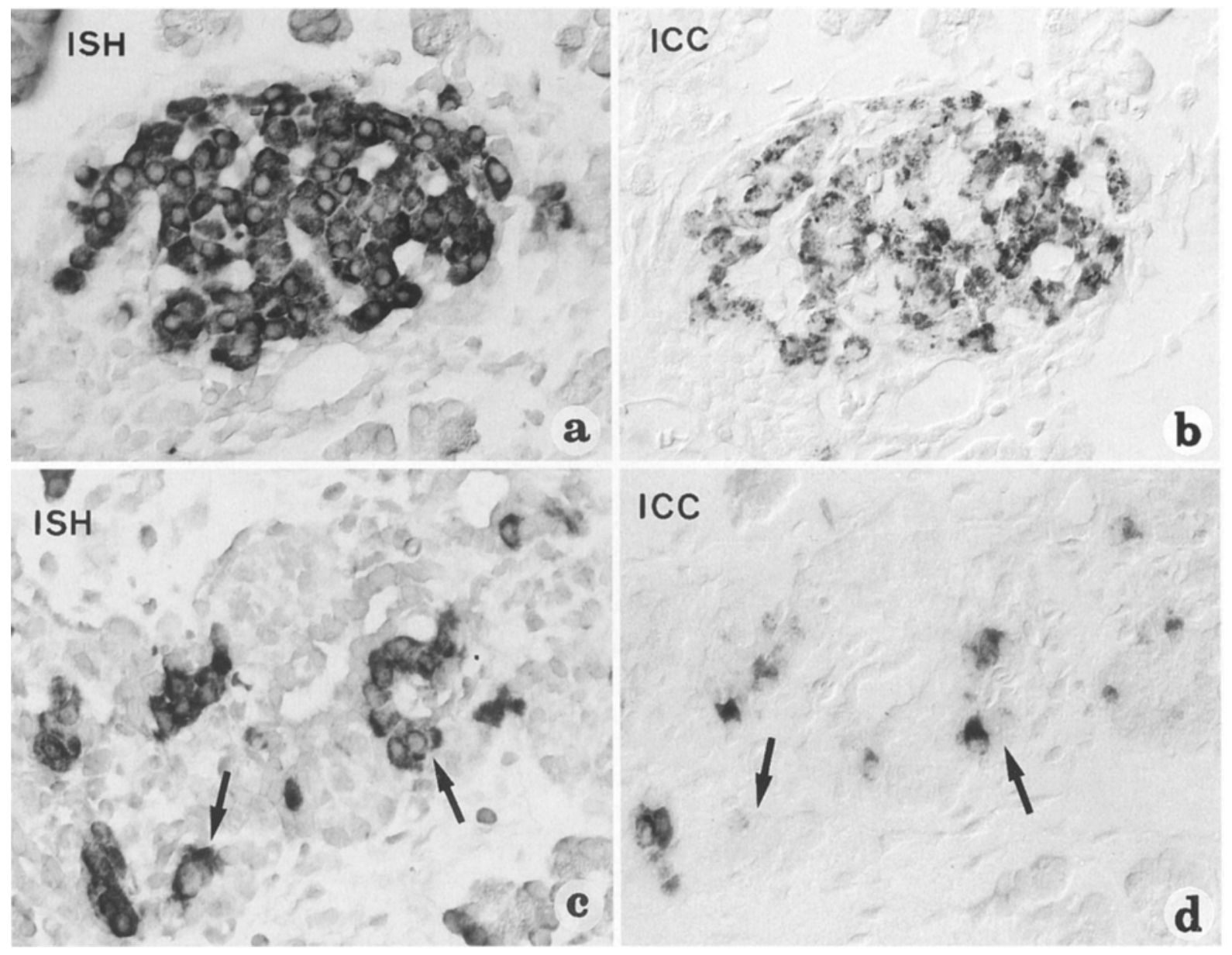

Fig. 4a-d. Comparison of in situ hybridization for rat preproinsulin mRNA and immunostaining for insulin in the pancreas of a neonatal normal $(\mathbf{a}, \mathbf{b})$ and STZ-rat $(\mathbf{c}, \mathbf{d})$ on day 2. (c) Some beta cells hybridized for preproinsulin mRNA (arrows), lacked immunostaining for insulin (d) (arrows). Original magnification. $\times 400$

delta cells) from intra- and extra-islet regions showed no significant differences between the two groups (Fig. 5).

\section{Morphometric Analysis}

Beta-cell volume: In control rats, the total beta-cell volume showed a three-fold increase during the first 5 days of life. The beta-cell volume was $0.356 \pm 0.03 \mathrm{~mm}^{3}$ on the day of birth and $1.074 \pm$ $0.067 \mathrm{~mm}^{3}$ at day 5 (Fig. 1 bottom). From day 5 to day 20 , there was no further significant increase. In STZ-rats, coinciding with the peak of hyperglycaemia, there was a severe reduction of the beta-cell volume on day 2 . After day 5 , it gradually increased, and at day 20 , it reached $39 \%$ of the control values. At all time points studied the beta-cell volume was significantly different between the control and STZ group $(p<0.001)$. The beta-cell volume of STZ-rats on days 2 and 5 based on the identification of beta cells by in situ hybridization (ISH) is shown in Figure 1 (the inset of bottom graph) and compared with the immunocytochemical results. This comparison shows that the beta-cell volume on day 2 based on in situ hybridization labelling is significantly higher than that based on immunocytochemical labelling.

Beta cell area: In the control group, the ratio of extraislet beta-cell area over total beta-cell area gradually decreased after birth. The same was observed in STZ-rats, but the ratio was significantly higher $(p<0.001$, Fig. 6). This was due to a marked reduction in the intra-islet beta-cell area, compared to a small reduction (on day 2 ) and later even an increase (on days 9,13 and 20) in the extra-islet beta-cell area in the STZ group (Fig. 7). The ratio of the non-beta (alpha and delta) cell area within and outside the islets showed no significant differences between the two groups (Fig. 7).

Size of individual Beta cells: In controls the mean cellular profile area of extra-islet beta cells was significantly smaller than that of intra-islet beta cells at days 0 and 2. The same was true for STZ-treated rats only on day 9 , but not at other time points (Table 2 ). No significant differences were found between the 


\section{Intra-islet}
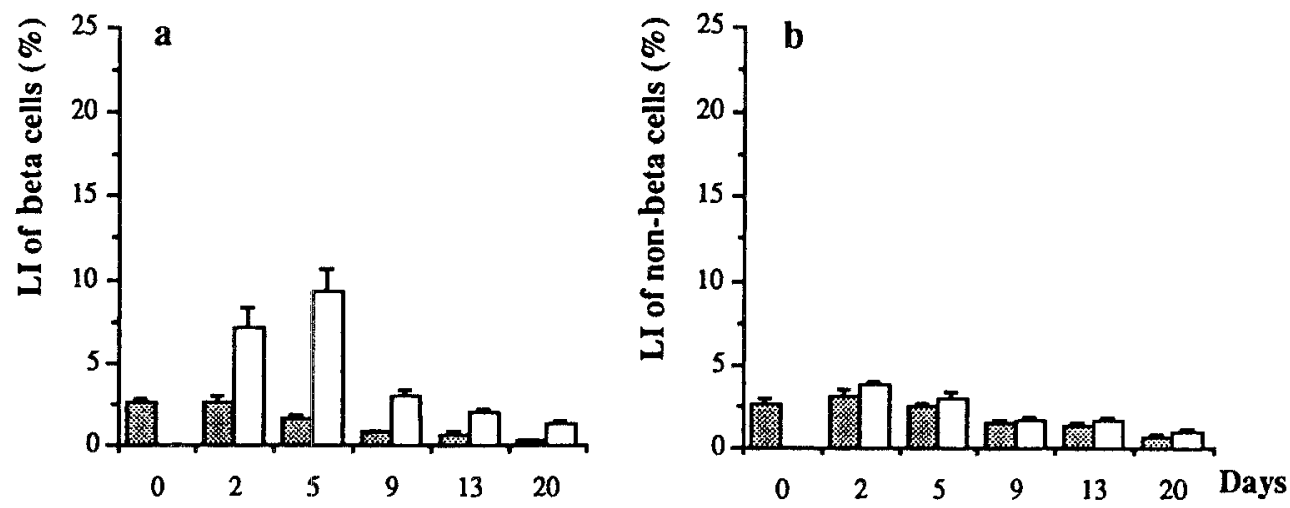

Extra-islet
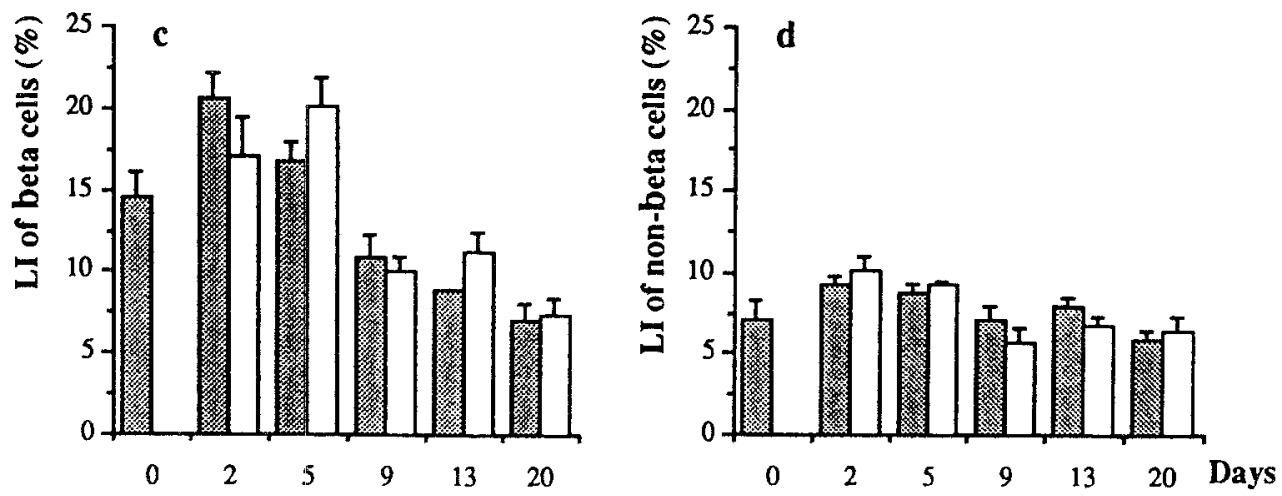

Fig. 5a-d. BrdU labelling indices (LI) of beta cells $(\mathbf{a}, \mathbf{c})$ or non-beta cells $(\mathbf{b}, \mathbf{d})$ within and outside the islets. Statistical analysis showed significant differences in (a) $p<0.001$, and no significant differences in $\mathbf{( b ,}, \mathbf{c}$, d). . Control, $\square$ STZ

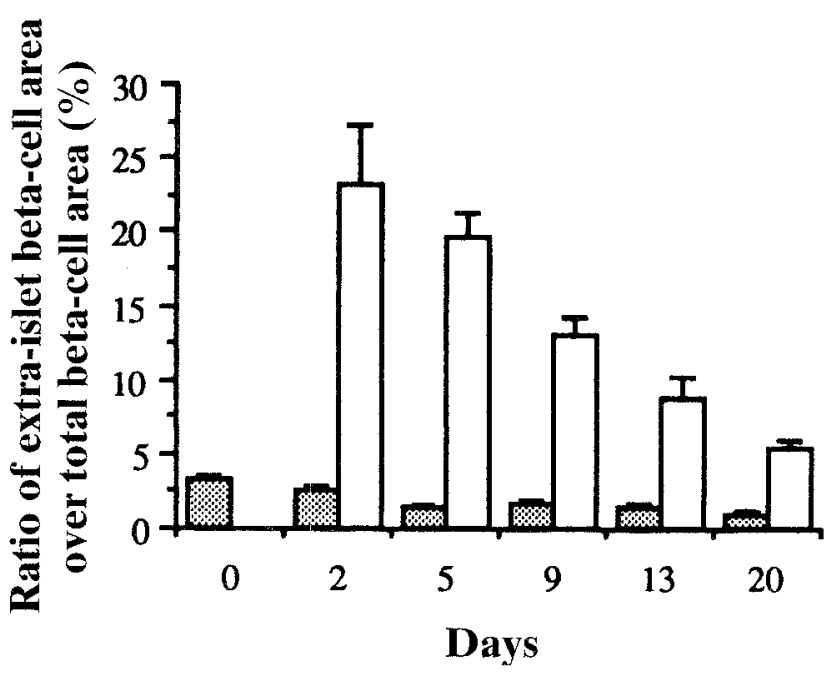

Fig. 6. Ratio of the extra-islet beta-cell area over the total beta-cell area. Values are expressed as percentage \pm SEM. 国 Control, $\square$ STZ

control and STZ rats for all time points tested, except for day 2 when the mean intra- and extra-islet betacell sizes were found to be smaller in STZ rats than in controls (Table 2).

Cell birth rate and growth rate of Beta-cell compartment. The values obtained for labelling index and beta-cell volume were used to calculate cell birth rate and the growth rate of the beta-cell compartment $\left(\mathrm{K}_{\mathrm{G}}\right)$ in normal and STZ-treated neonatal rats at different time points (Table 3 ). The cell birth rate and $\mathrm{K}_{\mathrm{G}}$ decreased in both groups with age. In STZrats, however, the cell birth rate of intra-islet beta cells was higher than that of normal rats $(p<0.01)$, whereas the cell birth rate of extra-islet beta cells was the same in normal and STZ rats. Comparison of the cell birth rate of intra-islet beta cells with the $\mathrm{K}_{\mathrm{G}}$ revealed a seven- to ten-fold lower cell birth rate in normal rats and three-fold rate in STZ-rats during the first 5 days (Table 3 ). The cell birth rate of extraislet beta cells, on the other hand, correlated well with the $K_{G}$ in both normal and STZ rats. When the $\mathrm{K}_{\mathrm{G}}$ in STZ rats at day 5 was calculated on the basis of the in situ hybridization results (see also Fig. 1), it was found to be lower than that based on immunocytochemistry results (Table 3 ).

\section{Discussion}

Studies in neonatal rats with STZ-induced diabetes have been controversial regarding the site of betacell regeneration [12-15]. In this investigation we demonstrate that regeneration of neonatal rat beta cells after subtotal destruction by STZ occurred by 


\section{Intra-islet}
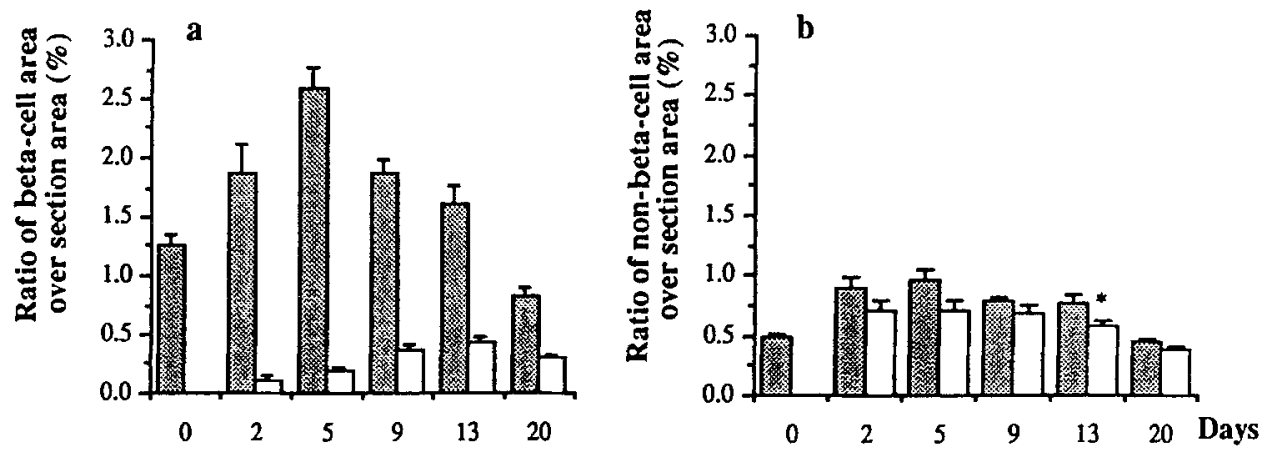

Extra-islet

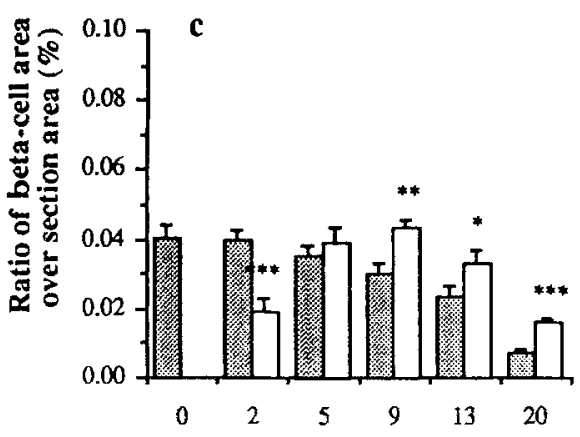

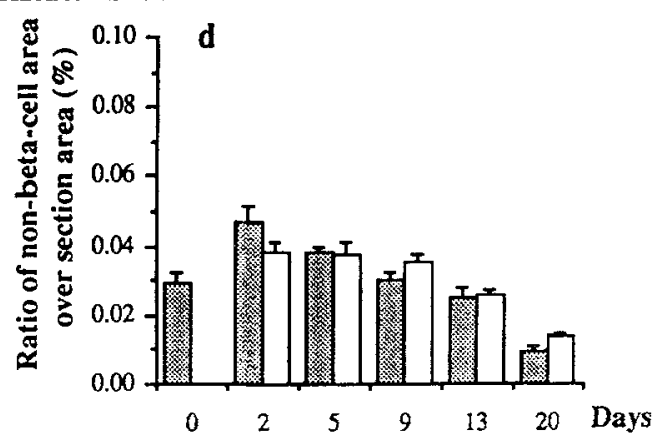

Fig. 7a-d. Ratio of total intra- or extra-islet beta-cell (a, c) or nonbeta (alpha and delta) cell area (b, d) over the whole pancreatic section area. Values are expressed as percentage \pm SEM. Statistical analysis showed significant differences between the two groups at all time points (a) $(p<0.001) ;(\mathbf{b}, \mathbf{c}, \mathbf{d}) * p<0.05$ $* * p<0.01 ; * * * p<0.001$. 酔 Control, $\square$ STZ

Table 2. Cellular profile area of individual intra- and extra-islet beta cells in normal and STZ-treated rats

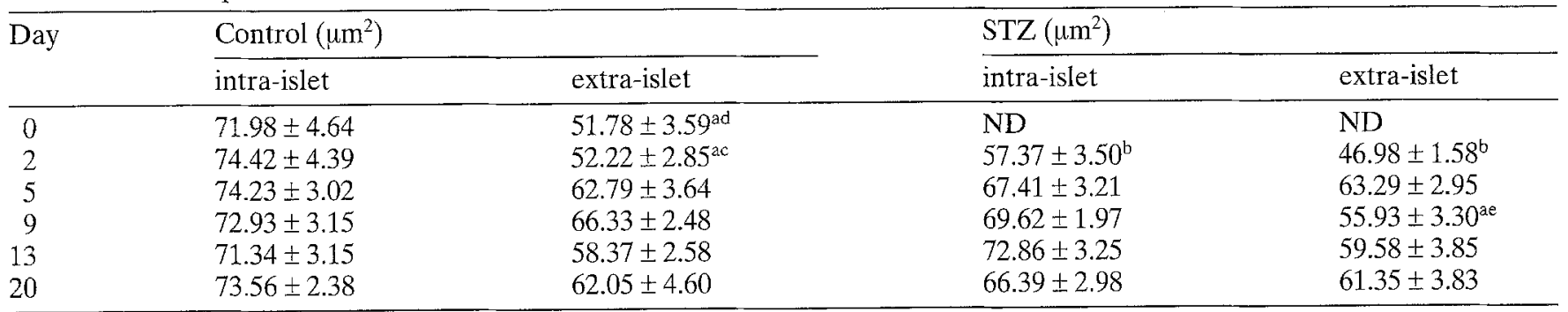

ND, not done. ${ }^{a}$ Comparison of intra- and extra-islet beta-cell values. ${ }^{b} p<0.05$ compared with the respective values in controls on day 2 and STZ rats on day $5 .{ }^{c} p<0.001,{ }^{d} p<0.01,{ }^{\mathrm{e}} p<0.05$

two mechanisms which are quantitatively of about equal significance. The first mechanism was a replication of surviving beta cells in the islet compartment; the second mechanism a replication of cells from a beta-cell pool outside the islet compartment. This contrasted with the situation in normal neonatal rats where beta-cell proliferation within the islets was much too low to account for the growth of the total beta-cell population.

In the normal neonatal rat pancreas, beta cells are either clustered in well-formed islets or present as single beta cells or small cell clusters scattered throughout the exocrine pancreas (extra-islet betacell compartment). The intra-islet beta-cell compartment showed a low proliferative activity, as demonstrated by BrdU labelling, which compares with a marked expansion of the total beta-cell population, as observed by morphometry. The cell birth rate ensuing from this activity was therefore much smaller than the growth rate of the total beta-cell volume, i. e. $6-10 \%$ versus $67-74 \%$ per day. These data indicate that about $90 \%$ of the beta-cell growth occurred outside the islet compartment. Examination of the extra-islet beta cell compartment revealed a high proliferative activity, with a cell birth rate similar to the observed growth rate of the total beta-cell volume. However, as the size of this compartment was less than $4 \%$ of all beta-cells, it was obviously too small to account for the observed growth of the total beta-cell volume. We therefore assume the existence of a precursor cell population which is responsible for beta-cell neogenesis and particularly feeds the extra-islet beta-cell compartment. The putative (yet to be identified) precursor cells may give rise to the small and possibly immature beta cells which compose the extra-islet compartment. Since ultrastructurally beta cells, either isolated or in small clusters, were commonly found to be associated with duc- 
Table 3. Comparison of cell birth rate (CBR) of intra- or extra-islet beta cells and growth rate $\left(K_{\mathrm{G}}\right)$ of the beta-cell compartment in normal and STZ-treated neonatal rats at different time points

\begin{tabular}{|c|c|c|c|c|c|c|}
\hline \multirow[t]{3}{*}{ Day } & \multicolumn{3}{|l|}{ Control } & \multicolumn{3}{|l|}{ STZ } \\
\hline & \multicolumn{2}{|l|}{ CBR } & \multirow[t]{2}{*}{$K_{\mathrm{G}}$} & \multicolumn{2}{|l|}{$\mathrm{CBR}$} & \multirow[t]{2}{*}{$K_{\mathrm{G}}$} \\
\hline & intra-islet & extra-islet & & intra-islet & extra-islet & \\
\hline 0 & $0.103 \pm 0.007$ & $0.55 \pm 0.06$ & - & ND & $\mathrm{ND}$ & - \\
\hline 2 & $0.102 \pm 0.006$ & $0.78 \pm 0.06$ & $0.74 \pm 0.12(9)$ & $0.234 \pm 0.026$ & $0.78 \pm 0.08$ & - \\
\hline 5 & $0.063 \pm 0.005$ & $0.64 \pm 0.05$ & $0.67 \pm 0.08(12)$ & $0.313 \pm 0.057$ & $0.76 \pm 0.08$ & $0.83 \pm 0.09(12)$ \\
\hline 9 & $0.028 \pm 0.002$ & $0.42 \pm 0.05$ & $0.28 \pm 0.02(7)$ & $0.108 \pm 0.010$ & $0.33 \pm 0.03$ & $0.56 \pm 0.08(7)$ \\
\hline 13 & $0.026 \pm 0.002$ & $0.33 \pm 0.03$ & $0.33 \pm 0.03(7)$ & $0.067 \pm 0.007$ & $0.42 \pm 0.03$ & $0.44 \pm 0.06(7)$ \\
\hline 20 & $0.011 \pm 0.001$ & $0.25 \pm 0.03$ & $0.16 \pm 0.01(6)$ & $0.050 \pm 0.005$ & $0.28 \pm 0.02$ & $0.29 \pm 0.06(6)$ \\
\hline
\end{tabular}

Calculated CBR and $K_{\mathrm{G}}$ rates are expressed as cells $\cdot$ cell $^{-1}$. day ${ }^{-1}$. The numbers of animals are given in parentheses. ND, not done. a $K_{G}$ calculated from the in situ hybridization results was $0.54 \pm 0.04$

tules, the putative precursor cells most likely belong to the ductal cell pool [6-11].

During the first 5 days of life we found a three-fold increase in the beta-cell mass which for the subsequent 15 days remained relatively constant. This suggests that the period crucial for the expansion of the neonatal beta-cell population may be limited to the first postnatal days, and it may even be speculated that the early neonatal period is decisive for the beta-cell volume of the adult pancreas. McEvoy [24, $25]$ also noted a much faster beta-cell growth during the first postnatal days than in a later period (days 10 to 20 ). However, in contrast to our results, he found only an increase in beta cells of about $50 \%$ between day 0 and 6 (when we had a $300 \%$ increase) and another $50 \%$ increase between days 6 and 10 (when we noted no further significant changes). So far, there is no ready explanation for these discrepancies but the use of different morphometric methods in McEvoy's and our studies may play an important role.

STZ administration on the day of birth reduced the total beta-cell volume on day 2 by $90 \%$. Since on day 20 only $39 \%$ of the normal beta-cell volume was regained, regeneration of the beta cells was incomplete. This finding which confirmed results from previous studies [14-16], has been used to explain the diabetes which is known to reappear at the age of 6 weeks [15-17]. The reason for the incomplete regeneration of the neonatal beta cells after their subtotal destruction is not known. One possibility is that restoration of normoglycaemia also abolishes the main stimulus for beta-cell regeneration. Alternatively, if neonatal beta-cell growth through neogenesis is largely restricted to the first days of life, beta-cell regeneration may be as well.

STZ particularly affected the beta cells within the islets because the reduction of the intra-islet betacell compartment was greater ( $>90 \%$ ) than that of the extra-islet beta cells. Thus, more than $20 \%$ of all surviving beta cells were found outside the islets where normally less than $4 \%$ are present. All the surviving beta cells were the size of normal extra-islet beta cells which were found to be smaller than normal intra-islet beta cells. Moreover, the BrdU labelling of surviving intra-islet beta cells was close to that of extra-islet beta cells. These observations further indicate that there may be a subpopulation of beta cells characterized by low sensitivity to STZ, small size and high mitotic activity, which may be intermediate in differentiation between presumptive (insulin-negative) beta-cell precursors and mature beta cells within the islets.

In the STZ-treated rats, the contribution of the intra-islet cell birth rate to total beta-cell growth was greater (i.e. up to $38 \%$ on day 5 , see Table 3 ) than in the normal neonatal pancreas where it was only $10 \%$. As it was conceivable that we underestimated the number of surviving beta cells on day 2 because of severe degranulation, we performed in situ hybridisation for preproinsulin mRNA and compared the mRNA-immunoreactive cell area with the proteinimmunoreactive cell area [26]. The analysis revealed that immunocytochemistry detected only $60 \%$ of the beta cells present in the islets at day 2, while there was no significant difference between hybridized and immunocytochemically labelled beta cells on day 5. This implies that the growth rate calculated for day 5 was overestimated since it was based on the protein immunoreactive area. Consequently, the contribution of the intra-islet cell birth rate to the actual growth could be higher and account for 50 to $60 \%$ of the total beta-cell growth. Replication from surviving intra-islet beta cells therefore represented at least an equally important regeneration mechanism after STZ-treatment as replication and probably neogenesis of beta cells from the extra-islet compartment.

It has been suggested that the neogenesis and proliferation of extra-islet "single" beta cells may give rise to new islets leading to an increase in the total number of islets in the pancreas $[12-13,27]$. This mechanism has also been discussed for beta-cell regeneration after STZ treatment $[14,16]$. However, this potential increase in islet number is difficult to quantify in absolute terms because of the stereologi- 
cal problems inherent to the variable shape and size of the islets [28]. As our studies on islet density were also inconclusive, we are not able to contribute to this difficult issue. However, considering the fact that the extra-islet beta-cell compartment is conspicuously reduced when neonatal and adult rat pancreata are compared, it is most likely that the extra-islet beta-cell clusters mature into fully-developed islets with aging of the pancreas.

In conclusion, the proliferation of immature-appearing extra-islet beta cells and their (yet to be identified) precursors probably represents the major mechanism of beta-cell generation in normal neonatal rats. After STZ destruction of beta cells, this mechanism seems to be of less importance, because the replication from pre-existing, surviving beta cells within the islets plays a quantitatively important role. The beta cells which survive STZ destruction presumably belong to a less differentiated, immature cell population which retains a high mitotic potential.

Acknowledgements. We thank Ms. N. Buelens and Ms. A. Nuyts for expert technical assistance; Dr. M. De Paepe for assistance with in situ hybridization; and Professor D. Pipeleers for helpful discussions. This study was supported by grant No. 3.0093 .90 of the National Belgian Research Council (NFWO).

\section{References}

1. Swenne I (1992) Pancreatic beta-cell growth and diabetes mellitus. Diabetologia 35: 192-201

2. Vinik AI (1992) Pancreatic islet cell regeneration and growth: introduction. Adv Exp Med Biol 321: 1-5

3. Welsh M, Mares J, Öberg C, Karlsson T (1993) Genetic factors of importance for $\beta$-cell proliferation. Diabetes/Metabolism Reviews 9: 25-36

4. Swenne I (1982) The role of glucose in the vitro regulation of cell cycle kinetics and proliferation of fetal pancreatic B-cells. Diabetes 31: 745-760

5. Hellerström C, Swenne I (1991) Functional maturation and proliferation of fetal pancreatic $\beta$-cells. Diabetes 40 [Suppl 2]: $89-93$

6. Rutter WJ (1980) The development of the endocrine and exocrine pancreas. In: Fitzgerald PJ, Morrison AB (eds) The pancreas, chapter 2, Williams and Wilkins, Baltimore pp 30-38

7. Dubois PM (1989) Ontogeny of the endocrine pancreas. Horm Res 32: 53-60

8. Fuji S (1979) Development of pancreatic endocrine cell in the rat fetus. Arch Histol Jpn 42: 467-479

9. Yoshinari M, Daikoku S (1982) Ontogenic appearance of immunoreactive endocrine cell in rat pancreatic islets. Anat Embryol 165: 63-70

10. Logothetopoulos J (1972) Islet cell regeneration and neogenesis. In: Steiner DF and Freinkel N (eds) Handbook of physiology, sect. 7 Endocrinology Vol.1 American Physiological Society, pp 67-76
11. Hellerström C (1984) The life story of the pancreatic $\beta$ cell. Diabetologia 26: 393-400

12. Cantenys D, Portha B, Dutrillaux MC, Hollande E, Rozé C, Picon L (1981) Histogenesis of the endocrine pancreas in newborn rats after destruction by streptozotocin. Virchows Arch B (Cell Pathol) 35: 109-122

13. Dutrillaux MC, Portha B, Rozé C, Hollande E (1982) Ultrastructural study of pancreatic $\beta$ cell regeneration in newborn rats after destruction by streptozotocin. Virchows Arch B (Cell Pathol) 39: 173-185

14. Bonner-Weir S, Trent DF, Honey RN, Weir GC (1981) Responses of neonatal rat islets to streptozotocin. Diabetes 30: $64-69$

15. Bonner-Weir S, Trent DF, Zmachinski CJ, Clore ET, Weir GC (1981) Limited B cell regeneration in a B cell deficient rat model: studies with dexamethasone. Metabolism 30: 914-918

16. Weir GC, Leahy JL, Bonner-Weir S (1986) Experimental reduction of $\beta$-cell mass: implications for the pathogenesis of diabetes. Diabetes/Metabolism Review 21: 125-161

17. Portha B, Levacher C, Picon L, Rosselin G (1974) Diabetogenic effect of streptozotocin in the rat during the perinatal period. Diabetes 23: 889-895

18. Soriano E, Del Rio JA (1991) Simultaneous immunocytochemical visualization of BrdU and neural tissue antigens. J Histochem Cytochem 39: 255-263

19. Aherne WA, Dunnill MS (1982) The estimation of whole organ volume. In: Aherne WA, Dunnill MS (eds) Morphometry, chapter 2, Edward Arnold Ltd., London, pp10-18

20. Komminoth P (1992) Digoxigenin as an alterative probe labelling for in situ hybridization. Diagn Mol Pathol 1: $142-150$

21. Williams MA (1985) Stereological techniques. In: Williams MA (ed), Quantitative methods in biology, chapter 2, North-Holland Ltd., Amsterdam, pp 5-84

22. Swenne I (1983) Effect of aging on the regenerative capacity of the pancreatic $\beta$-cells of the rat. Diabetes 32: 14-19

23. Aherne WA, Camplejohn RS, Wright NA (1977) An introduction to cell population kinetics. Edward Arnold, London, pp88

24. McEvoy RC, Madson KL (1980) Pancreatic insulin-, glucagon-, and somatostatin-positive islet cell populations during the perinatal development of the rat: I. Morphometric quantitation. Biol Neonate 38:248-254

25. McEvoy RC (1981) Changes in the volumes of the A-, B-, and D-cell populations in the pancreatic islets during the postnatal development of the rat. Diabetes 30:813-817

26. Van Gompel J, Mahler T, De Paepe M, Klöppel G (1993) Comparison of in situ hybridization and immunocytochemistry for the detection of residual beta-cells in the pancreas of streptozotocin-treated diabetic rats. Acta Diabetologica 30:118-122

27. Leduque P, Aratan-Spire S, Wolf B, Dubois PM, Czernichow P (1987) Localization of thyrotropin-releasing hormone- and insulin-immunoreactivity in the pancreas of neonatal rats after injection of streptozotocin at birth. Cell Tissue Res 248: 89-94

28. Hellerström C, Swenne I (1985) Growth of the pancreatic islets in animals. In: Volk BW, Arquilla ER (eds) The diabetic pancreas. 2nd edn. Plenum, New York, pp 53-79 